Isaac Shai

Dr Isaac Shai,

Postdoctoral Fellow,

Thabo Mbeki African

Leadership Institute,

University of South Africa;

E-mail: advocateshai@

gmail.com

DOI: http://dx.doi.

org/10.18820/24150479/

aa57i1.8

ISSN:0587-2405

e-ISSN: 2415-0479

Acta Academica - 2019 51(1):

144-162

(C) Creative Commons With Attribution (CC-BY)

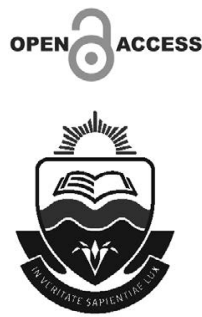

\section{Radical transformation and the limits of law}

First submission: 31 January 2018

Acceptance: 14 September 2018

This article evaluates the capacity of law and thus transformative constitutionalism to bring about radical transformation in South Africa. It is argued that the structural limits of law constrain the capacity of law and constitutionalism to bring about radical transformation in South Africa. Niklas Luhmann's systems theoretical approach is used to explore the limits of law. The article cautions against the unbridled bestowing of the reconstruction of South Africa on legal and constitutional mechanisms.

Keywords: Radical transformation, transformative constitutionalism, systems theory, constitutional reflexivity, normative closure

\section{Introduction}

In this article I explore critically the "limits of law" and accordingly the idea of transformative constitutionalism as a place and space for bringing about radical transformation in South Africa. The assumption is that law and thus the notion of transformative constitutionalism as was taken up in South Africa has structural limits that always already prevent radical transformation. The notion of the "limits of law" presupposes that the very essence of law as a phenomenon has limits and these limits are structural.

Drawing from Van Marle (2009: 294), I use the notion of the "limits of law" "in a radical sense, not 
in the sense that all lawyers to a certain extent concede the fact that law is a "limited structure". I therefore explore, from a systems theoretical approach, the "limits of law" and transformative constitutionalism and the implications of the "limits of law" on radical transformation in South Africa. Despite my reliance on Luhmann's insights on the systems theoretical approach, my focus is narrowed to how Luhmann's approach has been interpreted and developed by scholars such as Moeller (2012) and Christodoulidis (1991, 1994, 2004, 2011, 2016). According to Hanna (2013), Luhmann wrote about 70 books and more than 500 articles in his lifetime. However, only a few of his books on the subject of law have thus far been translated into English.

To endeavour a critical exploration of the "limits of law" and the idea of transformative constitutionalism is to acknowledge the pitfalls of unguarded euphoria and unrestrained optimism on the capacity of law and transformative constitutionalism to bring about radical transformation in South Africa. The probably apocryphal history and historiography of post-apartheid South Africa is a teleological one where good triumphs over evil. An ostensibly transformative constitution becomes the idea, space and place for the disruption of deeply imbedded racialised social pathologies and historical injustices on the one hand and a praxis for the attainment of radical transformation on the other.

The notion of transformative constitutionalism in South Africa has assumed paean status as the prism from which to enter the South African post-apartheid jurisprudential landscape. It is a neologism formulated by Klare (1998) to describe the South African Constitution (the Constitution) and its mandate. Klare (1998: 150) describes transformative constitutionalism as entailing

a long-term project of constitutional enactment, interpretation and enforcement ... to transforming a country's social and political institutions and power relations in a democratic, participatory and egalitarian direction. Transformative constitutionalism connotes an enterprise of inducing large-scale social change through nonviolent political processes grounded in law.

Imbedded in the logic of transformative constitutionalism as a project is the assumption of the potential for law to resolve the legacies of colonialism and apartheid. The assumption that law is capable of resolving the legacies of colonialism and apartheid fails to take sufficient cognisance of the possibility that law has limits. In this sense, and precisely because of these limits, the idea of relying on law and constitutionalism to resolve the legacies of colonialism and apartheid appears suspect. 
It is this notion of the "limits of law" and transformative constitutionalism that this piece takes up. The critique of transformative constitutionalism is largely based not so much on transformative constitutionalism as an ideal, but rather on the assumptions that undergird it. The aim is to critically explore the "limits of law" and transformative constitutionalism towards the attainment of radical transformation in South Africa.

The dominant narrative for the absence of radical transformation in South Africa is succinctly captured by Reddy (2016: 13) who states that the failure to bring about transformation is normally attributed to "a black government that is not providing the requisite leadership and delivery, the heaven it promised". In terms of this logic, what is required to induce radical transformation is a bold political leadership that is shorn of corruption and other forms of malfeasance.

The other equally dominant narrative is that while the Constitution is both progressive and transformative, it requires a change in legal culture to ensure a progressive and transformative interpretation of the goals contained in the Constitution (Klare 1998). In terms of these two dominant narratives, transformation, with or without its radical epithet, either requires "good politics" and/or a progressive interpretation of the Constitution. Imbedded in these two logics of "good politics" and a progressive interpretation of the Constitution is an a priori assumption that either politics can steer law or that law can steer other social systems such as the economy and religion so that either one or both of the "steerings" can bring about the much needed radical transformation.

I suggest that what is conspicuously absent in the two logics of the dominant narratives is the following: firstly, why the ostensibly good intentions of the Constitution have consistently remained just that - good intentions. Secondly, whether it is cogent to resolve centuries of colonialism and apartheid through legal and constitutional means. It is precisely the relationship, or the absence thereof, between constitutionalism and radical transformation that animates this reflection. Although reference is made to constitutionalism broadly, more focus is placed on the notion of transformative constitutionalism.

I therefore explore, from the systems theoretical approach, the "limits of law" and transformative constitutionalism and the implications of the "limits of law" and transformative constitutionalism on the attainment of radical transformation in South Africa. For reasons I have already mentioned, I draw from Luhmann's (1985, 2004) systems theoretical approach to analyse the "limits of law", but mainly rely on Moeller's (2012) and Christodoulidis's (1991, 1994, 2004, 2011, 2016) interpretation of Luhmann's systems theory. Having traversed the exposition of Luhmann's social systems theory through the lens of Moeller and its application to law and constitutionalism through Christodoulidis, I deploy the systems 
theoretical approach to critically analyse the potential pitfalls of transformative constitutionalism.

I suggest that the notion of transformative constitutionalism is unable to escape the structural limits of law. In my interpretation of the systems theoretical approach, law and constitutionalism, including the attribution of the neologism "transformative" to constitutionalism, are unlikely to completely succeed in ensuring the attainment of radical transformation in South Africa.

In the first part I explore the notion of radical transformation. The aim in this part is to attempt a working definition of the notion of radical transformation in order to firstly 'de-abstract' the notion and secondly, having 'de-abstracted' the notion, to explore whether law and the notion of transformative constitutionalism are capable of bringing about radical transformation. In the second part I explore the notion of transformative constitutionalism by firstly discussing the politicotheoretical loci of enunciation of Klare (1998) as the progenitor of the notion of transformative constitutionalism in South Africa. The politico-theoretical loci of enunciation serves as a critical jump-start to Klare's ultimate assumptions and conclusions that the Constitution is a transformative text.

In the third part I critically evaluate transformative constitutionalism against the systems theoretical approach. I commence with a brief exposition of the systems theoretical approach followed by a critique of the notion of transformative constitutionalism from a systems theoretical prism.

\section{Radical Transformation in South Africa}

One of the most enduring and powerful postcolonial myths is the notion that the elimination of colonial administration amounted to the decolonisation of the world (Ndlovu-Gatsheni 2007: 199). For Sardar (2008: xix), although direct colonial rule may have been eliminated, "colonialism, in its many disguises as cultural, economic, political and knowledge-based oppression, still lives on." Coloniality, described by Maldonado-Torres (2007: 243) as patterns of power that define culture, labour, inter-subjective relations and knowledge production, is still very much alive in South Africa. Incessant calls for decolonisation in South Africa are a reminder that coloniality does survive in the aftermath of colonialism. To borrow from Maldonado-Torres (2007: 243) once more, coloniality, in the aftermath of colonialism, "is maintained alive in books, in the criteria for academic performance, in cultural patterns, in common sense, in the self-image of people, in aspiration of self, and in so many other aspects of our modern experience". Informed by the enduring overt and covert aspects of colonialism, I propose a 
working definition of radical transformation to broadly encompass political, economic, and epistemological decolonisation.

In this sense, radical transformation should result in the reorientation of the very ontology and epistemologies of the oppressed, exploited and excluded. Radical transformation as a project should heed Fanon (1967: 250) when he states that "total liberation is that which concerns all sectors of the personality". Yet, radical transformation must also seek to avoid the espousal of "a nostalgic and uncritical return to pre-colonial past" (Gandhi 1998: 20) and should "treat the project of national liberation as an imaginative pretext for cultural selfdifferentiation from Europe and, thereby, as an attempt to exceed, surpass-even impose upon - the claims of western civilisation" (Gandhi 1998: 20).

The African National Congress (2007) describes its fundamental task as the "the liberation of Africans in particular and blacks in general from political and socio-economic bondage". Correct as the "political and socio-economic bondage" characterisation may be, there is sense in which it tends to shy away from unequivocally acknowledging that colonisation and apartheid in South Africa went beyond 'political and socio-economic bondage' but went on to

define culture, labour, inter-subjective relations, and knowledge production and is currently maintained alive in books, in the criteria for academic performance, in cultural patterns, in common sense, in the self-image of peoples, in aspirations of self, and so many other aspects of our modern experience (Maldonado-Torres 2007: 243).

This is precisely why the project of radical transformation must entail not only political and economic liberation but also ought to be an all-inclusive process of ontological and epistemological liberation - that is, total liberation as a logical conclusion of radical transformation. The question is whether transformative constitutionalism is capable of bringing about radical transformation.

\section{Transformative Constitutionalism and Radical Transformation}

\section{Critical Legal Studies as Klare's Politico-theoretical locus of enunciation}

It is an uncontroversial fact that American Critical Legal Studies (CLS) is characterised by what Hunt (1986:6-9)calls "theoretical synthesis", "syncretism", and "theoretical adoption" as opposed to "theoretical construction". In other words, CLS is an eclectic movement that draws intellectual inspiration from a 
wide trawl that includes the structuralism of Claude Levi-Strauss (that legal doctrine is a stereotyped pattern of contradictory imperatives), the existentialism of Jean-Paul Sartre (irreducible personal freedom and political responsibility of the judge at the side of a legal decision), the Marxism of Lukaćs (the politically and intellectually arrested state of American thought could be understood in terms of reification), Marx Weber's social theory (American law and legal thought as form of legitimation), Antonio Gramsci's hegemony, Jacques Derrida's notion of dangerous supplements and différance (indeterminacy of legal doctrine and legal theory), and Foucault's analysis of law in terms of power/knowledge (Schlag 2009: 297). For instance, a large segment of CLS forms part of the revisionist wing of Marxism which subscribes to the Marxian basis/superstructure topography (Hutchinson and Monahan 1998: 225).

On the other hand, "non-revisionists" such as Duncan Kennedy, Karl Klare and Roberto Unger reject the basis-superstructure notion and insist that "contemporary legal doctrine must be understood as an endless series of ad hoc, fragile compromises between contradictory ideals" (Hunt and Fitzpatrick 1987: 26). The two approaches differ on the issue of contingency. For the "revisionist", law as a super-structural phenomenon is contingent on the material basis of capitalism and as such can be traced back to economic forces and structures (Spitzer 2008: 23). For the "non-revisionist", the legal superstructure is capable of being the determining contingent on the material basis.

Hunt (2008: 154-155) reduces the different approaches above into to the "form determination" approach and the "concrete determination" approach. The differences in the two approaches inheres in that one approach's prism is the form of law (it looks at law from an external point) and the other approach's prism is the content of the law (it focuses on legal doctrines or the internality of law). The main CLS scholars aligned to the "concrete determination" include David Kairys, Morton Horwitz, Mark Tushnet and Karl Klare (Hunt 2008: 155). For these scholars "the law, though indeterminate, political and conservative, and though it functions to legitimate existing social and power relations, is a major terrain for political struggle that has, on occasion, yielded or encoded great gains and simply cannot be ignored by any serious progressive trend or movement" (Kairys 1998:16).

The "concrete determination" approach does not "as some progressive approaches have in the past, dismiss law as a sham or subterfuge; our criticism takes seriously the law's doctrines, principles, methods and promises" (Kairys 1998: 16). Klare (1998: 540) himself speaks about the aim being to "sketch ways of understanding law and legal processes and in particular, to develop a more critical and transformative conception of ... law and its practices." In 
accordance with this approach, law is full of possibilities, once its imbrication in liberal ideology is exposed and excised.

In "Law making as Praxis", one of his earlier articulations on the role of law, Klare (1979: 127-128), true to his "non-revisionist" and "concrete determination" approach, rejects the traditional Marxist instrumentalist approach and its conception of law in terms of which law was either a reflection of the base or law represented dominant class interests. Klare (1979: 133) advocates that we move from an "instrumental to a constitutive theory of law". The implications of this movement from instrumentalism to a constitutive theory of law are that law be treated as a terrain of struggle and emancipatory possibilities where it is possible to fill it with "humane content" (Klare 1979: 133).

For Klare (1979: 130), law-making should be conceived of as praxis. Klare (1979: 131) appropriates the Marxist notions of objectification and alienation as an analogy of how law making should be conceived of as praxis. It is here that Klare's Marxist humanist whiff becomes stronger (Levinson 1983: 1474). For Klare, the process of objectification inheres in the subject seeing itself in the object of its labour whereas alienation inheres in the subject not being able to identify the product of its labour. This leads to Klare's view that law making as praxis should be akin to objectification. For Klare (1979: 131), law making in a capitalist social formation, in the form of liberal legalism, resembles alienation. The clarion call for Klare (1979: 134) is that we must expose "the retrogressive character of the institutional and cultural practice embodied in the 'rule of law ideal', i.e., liberal legalism." The focus should be "on the regressive character of the form of law in capitalist society" (Klare 1979: 134). This is because law-making, for Klare (1979: 131), must be viewed "as a prospect or aspiration for democratic, and to some degree, anti-capitalist social change".

The centrality of Klare's "Law making as Praxis" inheres in that it is in this article that Klare advances what he calls a "constitutive theory" of law, which, 38 years later, is, to a large extent, still palpable and its aspects have come to be influential in South Africa's jurisprudential landscape in the form of transformative constitutionalism. Klare's description of transformative constitutionalism as "a long term project of constitutional enactment, interpretation and enforcement ... to transforming a country's political social institutions and power relations in a democratic, participatory and egalitarian direction" has the notion of "law making as praxis" written all over it.

Klare's Marxist humanism, which finds expression in his constitutive theory of law, the constitutive theory of law which morphs into transformative constitutionalism, can be summarised in the following manner: faith in law in that it is possible "to fill the law with humane content" (Klare 1979: 133) and legal culture can 
provide "a context and a moral basis for resistance to injustice" (Klare 1979: 133). As in the constitutive theory of law and the notion of transformative constitutionalism, Klare focuses more on law making, hence on adjudication and legal culture. What is palpably absent is a focus on law as a phenomenon. The focus on law-making as praxis has the consequence of leaving the ontology of law unattended and other equally important questions, such as the possibility that the very notion of law has structural limits that always already prevent radical transformation. Law making as praxis reaches apotheosis but further than that it is unable to account for, within the context of South Africa, the obstinate parallel existence between an ostensibly transformative constitutionalism on the one hand and the absence of radical transformation on the other. The systems theoretical approach attempts to provide reasons why an ostensibly transformative constitutionalism falls short of attaining its own objectives.

Despite pervasive constitutional optimism in South Africa, there are a few scholars who have sounded a warning on the capacity of both constitutionalism and transformative constitutionalism to bring about radical transformation. In particular, Sibanda (2012) and Ramose (2006) have relied on "exogenous" factors that render the attainment of radical transformation within the context of constitutionalism and transformative constitutionalism improbable. However, as I contend, despite Sibanda's and Ramose's cogent arguments, they still fall short of analysing the possible shortcomings or limits of law as a phenomenon.

\section{The exogenous factors of Ramose and Sibanda}

According to Sibanda (2012: 45), the notion of transformative constitutionalism has attained a "near hallowed status as the descriptor of the current project of constitutionalism". Sibanda's (2012: 44) view is that the major pitfall of transformative constitutionalism is that ultimately constitutionalism in South Africa is deeply imbedded within the liberal-democratic paradigm. "The prevalence of a liberal democratic constitutional discourse - despite the best intentions of transformative constitutionalism has had the effect of defining the goods of constitutionalism in narrower terms ... it is transformative constitutionalism's ostensible weddedness to liberal democratic constitutionalism that makes it ill-suited for achieving the social, economic and political vision it proclaims" (Sibanda 2012: 44). Although Sibanda agrees with the notion of legal culture as an impediment, he goes further to state that the problem is deeper than legal culture. According to Sibanda (2012: 51):

In a constitution that structurally and institutionally accords with the basic tenets of liberal democratic constitutionalism (a few innovations notwithstanding), transformative constitutionalism 
would, in practical sense, only appear to be achievable through sustained and purposeful legal and judicial interpretation demanding shared consciousness.

Sibanda's suggestion that transformative constitutionalism's imbrication in liberal democratic constitutionalism makes it ill-suited for achieving its social, economic and political vision is echoed by Ramose, albeit from a different angle. Ramose (2003: 491) argues for a "post-conquest constitution that must deal with the restoration of the title to territory and the reversion of unencumbered and unmodified sovereignty to the same quantum and degree as conquest". Ramose (2006: 15) contends that the eradication of poverty in Africa cannot succeed unless the Constitution is radically revised to ensure that Ubuntu as African philosophy becomes ubiquitous. Ramose's envisioned constitution will be based on justice and justice according to Ramose is the unconditional return of land. In a nutshell, Ramose's argument is that firstly, the paradigm of democratisation perpetuates colonisation because by constitutionalising an injustice, injustice is transformed into justice. The point of departure must be the return of land outside the boundaries of constitutionalism. The second argument he makes is that, having dealt with the question of injustice, a new constitution must then put at its centre African Philosophy in the form of Ubuntu. Ramose presents a cogent analysis relating to the separation of justice and law. However, his argument that Ubuntu be a constitutional philosophy is susceptible to being labelled a form a radical republicanism in that once Ubuntu becomes a constitutional matter, it ipso facto becomes a legal matter to be subjected to the vagaries and structural limitations of law and legal interpretation.

Central to both Sibanda's and Ramose's scepticism about the capacity of constitutionalism and transformative constitutionalism to bring about radical transformation is the limitations of liberal democracy and the limitations of the democratic paradigm as opposed to the decolonisation paradigm respectively. However, both Sibanda and Ramose's critiques, while refreshingly radical, do not sufficiently deal with the phenomenon of law and its innate structural limits. Both seem to suggest the possibilities and the capacity of functional systems to steer one another - a view that is that at variance with the system theoretical approach.

\section{Systems theory, Radical Transformation and Transformative Constitutionalism}

\section{A Systems Theoretical approach to Law}

In this part I suggest that from a systems theoretical prism, the possibilities of law and constitutionalism, including the adoption of a transformative approach 
to constitutionalism, in ensuring the attainment of radical transformation in South Africa are unlikely to succeed. This suggestion is informed by the systems theory's characterisation of society under capitalism as being based on functional differentiation. In terms of the system theoretical approach, "under the conditions of functional differentiation and operational closure, there is no institution, organisation, system, or group in society that can steer society as a whole. Systems steer themselves." (Moeller 2012: 24). The political system can only irritate or perturb the legal system and the legal system can only perturb or irritate the economic system and as such "steering is always self-steering of systems" (Moeller 2012: 24). This obviously is in contrast with the western enlightenment heritage that assumes that politics and political institutions, and law and legal institutions, are natural instruments that can be used by human being's to control, steer and guide society (Moeller 2012: 25). For Moeller (2012:25) systems theory refutes the notion that society is based on unity but rather it insists that society is based on distinctions and differences. Systems theory refutes the Platonic notion of society based on universal reason and rationality. It argues that reason and rationality are either contingent on or are a result of construction by the system (Moeller 2012: 25).

The systems theoretical approach suggests the impossibility of politics subsisting peacefully in law. This is because for politics to subsist peacefully in law, it has to be observed by law and its complexity be reduced, thus becoming law and therefore ceasing to be politics but law. The impossibility of the naked transfer of moral conceptions or political goals into the legal system has been pointed out. This is not to suggest that law only deals with law. If this were the case, then law would only be normatively or operationally closed and that would be the end of the story. Hence it is also said that the law is also cognitively open.

The cognitive openness of law presupposes that law is able to deal with other systems of a political and economic nature. These other systems however enter as facts or information - as cognition. The law uses them to reason. However, law's cognition of the cognitive is achieved by law using its own categories of evaluation and interpretation. When law cognises, it essentially asks itself one question: is the cognitive legal or illegal. If the cognitive is illegal, it is wrong and if it legal, it is right. Hence there exists a legal right and a legal wrong. This means that in instances where society is juridified, in instances where politics is observed by law (Teubner 1993: 109), the political is forcefully subjected to the coding of the law.

Luhmann's approach is to first give an account of society as a whole and then proceed to deal with law's place within society in terms of the systems theory and whether law as a sub-system has the ability to influence other social sub-systems (Paterson 2006: 16). Paterson (2006: 13) correctly states that, notwithstanding 
Luhmann's view on the inability of law to engineer society, there is traditionally something "counterintuitive and perverse" about Luhmann's view, particularly for a state of affairs which has traditionally viewed law as a tool for change.

This is because Luhmann fundamentally rejects the claim that law has the capacity to improve society, control populations or engage in social engineering (King 2006: 41). Luhmann's rejection of the capacity of law to improve society and engage in social engineering is in tandem with his rejection of the enlightenment project which seeks to improve society through the deployment of human rationality (King 2006: 41). According to King (2006: 41), Luhmann rejects the claim that human rationality is capable of solving social problems and refutes the "taken for granted world as the only reality or authoritative attribution of causes as having universal validity" and possesses "a total scepticism concerning the ambitions of law and politics to regulate social behaviour in a reliable and predictable manner". As a result Luhmann rejects the view of law as a force for progress in society or "an effective or potentially effective instrument for regulating and controlling events" (King 2006: 42). This, as stated earlier, is based on Luhmann's notion of normative closure of autopoietic or closed systems and the fact that normative closure presupposes self-steering of systems.

In The Inertia of Institutional Imagination, Christodoulidis (1996: 378) succinctly puts the relation between law and transformation in the following words:

If law does harbour transformative opportunities it is because there are limits to law's institutional imagination that take the form of reductions which, at a deep level, cannot but remain in place ... law cannot but foreclose broader political conflict and, in the last instance, assimilate transformative opportunity to its own self-maintenance and assimilate the disruptive to its own controlled evolution.

I suggest that Christodoulidis's assertion is that the supposed transformative opportunities offered by law are always already legal opportunities. These opportunities are always already opportunities limited by institutional inertia. They are opportunities of law, for law and by law. The very fact that they present themselves as opportunities is based on what Luhmann calls law's reduction achievement. They are opportunities that arise after the law has reduced complexity and has consequently excluded that which is not relevant to it - other politics. Christodoulidis (2003: 414) states that it is precisely law's reduction of complexity, its ability to exude conflict as resolvable and its ability to bring conflict to finality "that give constitutionalism its specific legal nature and institutional achievement'.

The next logical question for transformative constitutionalism is whether it is capable of escaping or wrestling itself away from the clutches of law's 
institutional inertia. This is so because in the final analysis, imbedded in the logic of transformative constitutionalism is constitutional optimism and thus a belief in constitutional and legal reflexivity.

\section{Systems theory and transformative constitutionalism}

As stated earlier, for Klare (1998: 150) transformative constitutionalism entails "a long term project of constitutional enactment, interpretation and enforcement ... to transforming a country's political social institutions and power relations in a democratic, participatory and egalitarian direction. Transformative constitutionalism connotes an enterprise of inducing large-scale social change through non-violent political processes grounded in law."

It is about ensuring the

redistribution of power and resources along egalitarian lines.

The challenge of achieving equality within this transformation project involves the eradication of systemic forms of domination and material disadvantage based on race, gender, class and other grounds of inequality. It also entails the development of opportunities which allow people to realise their full human potential within positive social relationships (Langa 2006: 352).

Transformative constitutionalism must ensure "the achievement of substantive equality and social justice, the infiltration of human rights norms into private relationships and the fostering of a culture of justification for every exercise of power" (Pieterse 2005: 156).

Based on the foregoing, I hazard the following as what I understand to be the essence of transformative constitutionalism: transformative constitutionalism entails large scale social change and the content of this social change entails redistribution of power and resources so as to achieve substantive equality and social justice. This envisaged transformation must however be grounded in law and ensue within constitutional arrangements.

Based on the above statement, the measure of success of transformative constitutionalism would be its ability to ensure that power is redistributed in an egalitarian manner; and domination and material disadvantage based on race, gender and class are eradicated. In this sense, power and resource must be equally shared and material disadvantage must not be based on race or, put differently, disadvantage must be equally carried. All these must of course occur within constitutional arrangements. The sharing of power, the distribution of resources and the sharing of disadvantages ought to be achieved within constitutional arrangements - hence section 2 of the Constitution which states 
that the Constitution is the supreme law of the Republic and law or conduct inconsistent with it is invalid.

The first glaring subtext of the above statement is that it is a confirmation of the fact that, particularly within the context of South Africa, material resources are extremely contested. The history of South Africa is such that the majority of its citizens happen to be those who are mostly disadvantaged and less resourced. The minority, which is mainly white, is the more advantaged and well resourced. Inevitably, those with resources would naturally want to keep their resources and those who have no resources would naturally want these resources to be "redistributed". Therefore any contestation over resources can only be between those who own the resources and are reluctant to give them up (which may result in the sharing of disadvantages as per the statement above) and those who are in need of the resources and are not able to access them because those who own them are reluctant to give them up.

Transformative constitutionalism therefore becomes a solution for ensuring that this contestation is (re)solved by and within constitutional arrangements and in an orderly manner facilitated by and within the constitutional arrangements. In this manner of transformative constitutionalism, "the constitutional arrangements stabilise objectively valid expectations and the absorption of uncertainty occurs at the level of the setting up of a context of disagreement" (Christodoulidis 2003: 414). At face value, this approach looks sensible in that the setting for contestation has been fixed and any person who contests an issue is aware and agreed with the setting for a disagreement.

I suggest that imbedded in the logics of the notion of transformative constitutionalism is constitutional optimism (republicanism), the assumption that systems can "steer" other systems, politics can find expression in law, and generally the belief, which is constitutionalism's overriding logic, in constitutional reflexivity. I now turn to subject the notion of transformative constitutionalism to a system theoretical critique, informed by our understanding of what constitutes radical transformation.

\section{A systems theoretical critique of transformative constitutionalism}

Christodoulidis (2003: 404) contends that the predominant orientation among both the liberal and left-wing democrats towards constitutional theory, notwithstanding their nuanced variations, is that of viewing constitutionalism as a form of empowerment. What binds constitutionalists is their sense of "constitutional optimism" expressed in their convergence on normative issues 
such as the need for "unity in political diversity", a "shared constitutional identity" or a "common moral reading of the constitution" (Christodoulidis 2003: 404).

In short, they are all agreed that constitutionalism has the capacity to contain politics. Van Marle (2007), in reference to Christodoulidis, is suspicious of this republican view. Van Marle (2007: 419) states that Christodoulidis is very
critical towards the attempt of critical scholars (like Karl Klare)
to disrupt the legal system's tendency of assimilation and
rationalisation by seeking deviations and contradictions as
intellectual and political opportunities by drawing from the system itself. Reflecting on the ideals of transformativeconstitutionalism and human rights, one must ask whether we are attributing more to law's capacity than we should.

In terms of the systems theoretical approach, an approach that is characterised by constitutional optimism and thus constitutional reflexivity is an approach that fundamentally believes in a hierarchy of systems and the fact that systems can 'steer' one another.

I have already suggested that in terms of the system theoretical approach, society as a system is nothing but a totality of communications. Out of the broader societal system emerge a multiplicity of sub-systems, be they an economic sub-system, a political sub-system or a legal sub-system. Each of these sub-systems develops "a selective and exclusive mapping of the world" (Christodoulidis 1998: 84). This process of selectivity and mapping of the world occurs through the sub-system differentiating itself from society. This differentiation is called "the system/environment distinction" (Christodoulidis 1998: 84). A system therefore observes by making differentiation a "guiding difference" (Christodoulidis 1998: 82). "Semantic codes specify the difference, which form the basis for something to be received as information" (Christodoulidis 1998: 82). Therefore a pattern of difference lies at the basis of the system's observation (Christodoulidis 1998: 82).

The system observes by reduction of complexity. The reduction of complexity by the system occurs when the system selects what must come into the system. The normative communication of other systems must, for instance "request permission" to enter into the legal system. But for them to obtain permission to enter into the legal system, they have to first be reconstructed as law, and therefore become law (King: 1993: 227). "Once reconstructed within law, [and having become law], philosophical, moral or religious statements become part of the meaning system of law, subject to its reproductive procedures and prevailing realities" (King 1993: 227) In this way law observes its environment by reducing complexity, by simplifying its environment. Put simply, the law says that if you 
want to use me for your purposes, you first have to seek permission from me and for me to give you permission to be part of me I have to change you into me. Once I have changed you into me, you lose your character. For other normative communication to enter into law, the law has to capture their souls.

In the final analysis, I suggest that the effect of bestowing a transformational project on the legal system is much more pungent in the parallel existence of an ostensibly progressive, transformative and "post-liberal" (Klare 1998) Constitution on the one hand and persistent problems of poverty, unemployment and inequalities on the other. Of course the dominant narrative attributes the absence of radical transformation in South Africa to, among others, corruption, racism, low levels of skills among black people, land dispossession, state incapacity and low levels of foreign direct investments. These arguments usually proceed to emphatically state that the problem cannot be the Constitution because, on the contrary, the Constitution allows and yearns for radical transformation. In this sense it is incorrect to attribute the absence of radical transformation to the Constitution. I agree that it is incorrect to blame the Constitution for South Africa's persistent maladies. However, I suggest that it is equally unrealistic to expect the idea of radical transformation to unfold unhindered within the spatio-temporal locus enunciated by transformative constitutionalism. The most apposite example is the notion of socio-economic rights in South Africa.

In the "Political Economy of European Social Rights", Christodoulidis and Goldini (2016: 1) ask why, despite the 2008 economic crisis, did the paradigm of legal protection of social rights continue to gain momentum? Christodoulidis and Goldini (2016: 3) correctly state that there always almost exists an incongruous moment between the logic of capital and the protection of social rights and the inevitable trumping of social rights by and due to the nature of liberal capitalist arrangements. This is because "political economy undergirds social rights constitutionalism" and social rights yield to the logic of the market (Christodoulidis \& Goldini 2016: 8). The incongruous moment between the logic of capital and the protection of social rights is but one salient example of the inability of systems to steer one another. In this sense the dialogic space envisaged by the notion of transformative constitutionalism wherein societal antagonisms are negotiated is undercut by the inertia of societal sub-systems, including that of law and the economy. Where the idea of transformative constitutionalism suggests law and constitutionalism are able to steer other sub-systems, the continued parallel existence of transformative constitutionalism and the absence of radical transformation exemplifies the inability of systems to steer one another. 


\section{Conclusion}

The essence of the systems theoretical approach is that it "de-anthropologizes" the description of society and in that way moves away from anthropocentric views of society (Moeller 2012: 5). In this way, the human is 'de-centred' and human being's cease to be the centre of society. This approach, as stated earlier, does not presuppose the non-existence of human beings, but rather the fact that if society is looked at from the point of functional differentiation as opposed to stratification, we see systems as opposed to class only. Functional differentiation of society allows for the dissolution of the ostensible hierarchy that is constitutive of society. The dissolution of the hierarchy also leads to the understanding of the inability of systems to steer one another. As indicated, this inability to steer is based on the closure of systems.

In this article I have suggested the need to guard against unbridled optimism regarding transformative constitutionalism as an idea, space and place for the disruption of coloniality. Drawing from the systems theoretical approach, I have cautioned that the structural limits of law and the inability of societal subsystems to steer one another tamper with the optimistic expectations present in the notion of transformative constitutionalism. More importantly, the effects of bestowing transformation on the legal system are more evident in the persistent problems of unemployment, inequalities and unemployment. I have contended that while the dominant narrative on the inability to radically transform South Africa is predominantly attributed to corruption, racism, state incapacity, among others, and that there is merit to some of these diagnoses, the discourse on the prescription is analytically suspect. To subject radical transformation to what ultimately morphs into a rights discourse may not be useful in reconstructing a country such as South Africa.

\section{Bibliography}

CHRISTOdOULIDIS E. 1991. A case for reflexive politics: challenging Luhmann's account of the political system. Economy and Society 20(4): 380-401. https:// doi.org/10.1080/03085149100000020

CHRISTOdOULIDIS E. 1996. The inertia of institutional imagination: a reply to Roberto Unger. Modern Law Review 59(3): 377-397. https://doi. org/10.1111/j.1468-2230.1996.tb02086.x

CHRISTODOULIDIS E. 1998. Law and reflective politics. Dordrecht: Kluwer. HTTPS:// DOI.ORG/10.1007/978-94-011-3967-0

Christodoulidis E. 2003. Constitutional irresolution: law and the framing of civil society. European Law Journal 9(4): 401-414. https://doi. org/10.1111/1468-0386.00184 
CHRISTOdOULIDIS E. 2004. 'End of history' jurisprudence: Dworkin in South Africa. Acta Juridica 2004(1): 64-85.

CHRISTOdOULIDISE. 2011. Depoliticising poverty: ArendtinSouth Africa. Stellenbosch Law Review 22(3): 501-520.

ChRISTOdOULIDIS E AND GoLDINI M. 2016. The political economy of European social rights. Available at: https://www.academia.edu/30815819. https://doi. org/10.2139/ssrn.2891306

FANON F. 1967. The wretched of the earth. Transl Farrington C. London: Penguin.

GANDHI L. 1998. Postcolonial theory: a critical introduction. Edinburg: Edinburg University Press.

HANNA M. 2014. Luhmann's other book on law: observations on the reception of Niklas Luhmann's A sociological theory of law. Soziale Systeme 19(1): 152-160. https://doi.org/10.1515/sosys-2014-0109

Hunt A ANd FitZPATRICK P. 1987. Critical legal studies. Journal of Law and Society 14(1): 1-3. https://doi.org/10.2307/1410292

HUNT A. 2008. The Ideology of law: advances and problems in recent applications of the concept of ideology to the analysis of law" In: Easton S (ed) Marx and law. Aldershot: Ashgate.

HUTCHINSON A AND MONAHAN PJ. 1984. Law, politics and the critical legal scholars: the unfolding drama of American legal thought: Stanford Law Review 36(1/2): 199-245. https://doi.org/10.2307/1228683

KAIRYS D (ed). 1998. The politics of law: a progressive critique. New York: New York Basic Books.

KING M. 1993. The 'truth' about autopoiesis. Journal of Law and Society 20(2): 218236. https://doi.org/10.2307/1410168

KING M. 2006. What's the use of Luhmann's theory. In: King M \& Thornhill C (eds). Luhmann on law and politics: critical appraisals and applications. Oxford: Hart.

KLARE K. 1979. Law-making as praxis. Telos 1979(40): 123-35. https://doi. org/10.3817/0679040123

KLARE K. 1998. Legal culture and transformative constitutionalism. South African Journal of Human Rights 14(1): 146-188. https://doi.org/10.1080/02587203. 1998.11834974

LANGA P. 2006. Transformative constitutionalism. Stellenbosch Law Review 17(3): 351-360.

LEVINSON S. 1983. Escaping liberalism: easier said than done. Harvard Law Review 96(5) 1466-1488. https://doi.org/10.2307/1341011

LUHMANN N. 1985. A sociological theory of law. London: Routledge.

Lummann N. 1990. Political theory in the welfare state. Berlin: Walter de Gruyter.

LUHMANN N. 1993. Deconstruction as second-order observing. New Literary History 24(4): 763-782. https://doi.org/10.2307/469391 
LUHmann N. 1987. The unity of the legal system. In: Teubner G(ed). Autopoietic law: A new approach to law and society. Berlin: Walter de Gruyter. https://doi. org/10.1515/9783110876451.12

MALDONADO-TORRES N. 2007. On the coloniality of being. Cultural Studies 20(1): 240-270. https://doi.org/10.1080/09502380601162548

MIGNOLO W. 2007. Delinking: the rhetoric of modernity, the logic of coloniality and the grammar of decoloniality. Cultural Studies 21 (2) 449-514. https://doi. org/10.1080/09502380601162647

MoelLer H. 2012. The radical Luhmann. New York: Columbia University Press.

NdLovU-GatShenI SJ. 2014. The Idea of the African National Congress, democratic paradox and the stubborn spectre of coloniality. In: Ngcaweni B (ed). The future we choose: emerging perspectives on the centenary of the ANC. Africa Institute of South Africa: Pretoria.

PATERSON J. 2006. Reflecting on reflexive law. In: King M and Thornhill C (eds). Luhmannonlawandpolitics: criticalappraisalsandapplications. Oxford:Hart.

Pieterse M. 2005. What do we mean when we talk about transformative constitutionalism. South African Public Law: 20(1) 155-166.

RAMOSE M. 2006. Philosophy and Africa's struggle for independence. Politeia: 25 (1) 3-17.

RAMOSE M. 2003. I conquer, therefore I am the sovereign: reflections upon sovereignty constitutionalism, and democracy in Zimbabwe and South Africa. In: Coetzee P H and Roux A J P (eds). Philosophy from Africa: a text with readings. London: Routledge.

REDDY T. 2016. South Africa, settler colonialism and the failures of liberal democracy. Johannesburg: Wits University Press.

Roux T. 2009. Transformative constitutionalism and the best interpretation of the South African constitution: distinction without a difference. Stellenbosch Law Review: 20 (2) 258-285.

SARDAR Z. 2008. Foreword to the 2008 Edition. In: Fanon F. Black Skin White Masks. Pluto: London.

SCHLAG P. 2010. Critical legal studies. In: The Oxford international encyclopaedia of legal history. Available at: https://ssrn.com/abstract=1632981.

SIBANDA S. 2011. Not purpose-made! Transformative constitutionalism, postindependence constitutionalism, and the struggle to eradicate poverty. STELLENBOSCH LAW REVIEW 22(3): 482-500.

SPITZER S. 2008. Marxist perspectives in the sociology of law. In: Easton S(ed). Marx and Law. Ashgate: Hampshire.

StRATEGY AND TACTICS OF THE ANC. 2007. Building a national democratic societyrevised draft. Available at: www.anc.org.za/content/strategy. 
TeRREBLANCHE S. 2002. A history of inequality in South Africa 1652-2002. Durban: University of KwaZulu Natal Press.

TERREBLANCHE S. 2012. Lost in transformation. Sandton: KMM Review.

TeUbneR G. 1987. Introduction to autopoietic law. In: Teubner G (ed). Autopoietic Law: A new approach to law and society. Berlin: Walter de Gruyter. https://doi. org/10.1515/9783110876451.217

TEUBNER G. 1993. Law as an autopoietic system. Blackwell: Oxford.

VAN MARLE K. 2007. The spectacle of post-apartheid constitutionalism. Griffith Law Review 16(2): 411-429.

VAN MARLE K. 2009. Transformative constitutionalism as/and critique. Stellenbosch Law Review 20(2): 286-301. https://doi.org/10.1080/10383441.2007.10854597 